\title{
Perancangan Injection Blowing Tools dengan Line Slider untuk Mesin Blow Molding dengan Kapasitas Volume $\mathbf{3 0 0} \mathrm{MI}$
}

\author{
Subkhan Nur lkhsan ${ }^{\mathrm{a}}$, Cahyo Budiyantoro ${ }^{\mathrm{b}}$, Totok Suwanda ${ }^{\mathrm{c}}$, Adi Nugroho ${ }^{\mathrm{d}}$ \\ ${ }^{a, b, c}$ Program Studi Teknik Mesin, Fakultas Teknik, Universitas Muhammadiyah Yogyakarta \\ Jalan Brawijaya, Kasihan, Bantul, Daerah Istimewa Yogyakarta, Indonesia (55183) \\ e-mail: subkhan.nur.Ikhsan@gmail \\ ${ }^{\mathrm{d}}$ Politeknik ATMI Surakarta \\ Jl. Mojo No. 1, Karangasem, Laweyan \\ Surakarta - 57145 \\ Phone: +62 (0) 271714466
}

\begin{abstract}
Blow Molding Machine is a bottle printing machine with a working system blowing soft bottle preform $\left( \pm 100^{\circ} \mathrm{C}\right)$ with air pressure of 7 bars. In injection blowing tools, there are two main components, namely injection tools which are in charge of delivering high-pressure air from the compressor to the bottle preform and line slider which is tasked to drive the mold cavity when the injection process will be carried out and completed. The main material used in the line slider is low carbon type $A 36$ steel $(0.25 \%-0.29 \%$ C) with plate type with a strength of $360 \mathrm{Ksi}$ $(250 \mathrm{MPa})$, while in the injection tools section uses aluminum-alloy 4032 material (Al, Si $12.5 \%, \mathrm{Mg}, \mathrm{Cu}$, Ni). These materials are easily processed at economical prices. The injector and blow pin parts of the shaft holder use 304 stainless steel material with a strength of $515 \mathrm{MPa}$. The interconnection process between components uses a welded connection with fillet type with an average height of $3 \mathrm{~mm}$ weld neck and uses RD-260 type electrodes which belong to the E6013 electrode with a maximum voltage limit of $60 \mathrm{ksi}$. In other parts, the connection between the type of bolt and nut is used from SS 304 material with size M6 M16. Large development ratio at injection process (BUR) of 4 with bottle size preform length $99 \mathrm{~mm} 2 \mathrm{~mm}$ thick and inner diameter $26 \mathrm{~mm}$.
\end{abstract}

Keywords: Blow Molding, Injection Blowing Tools, Injector Tools, Line Slider

\section{Pendahuluan}

Salah satu pemakaian plastik pada makanan dan minuman yaitu untuk kemasan botol air mineral dengan berbagai macam bentuk yang menarik. Peluang yang besar tersebut menjadikan motivasi dalam pembuatan mesin pencetak botol plastik yaitu blow molding machine.

Blow molding machine adalah sebuah mesin yang memiliki prinsip kerja mencetak bottle preform dengan cara ditiup. Bottle preform yang telah dipanaskan dan kemudian dimasukkan ke sebuah cetakan (mold cavity) lalu diinjeksi dengan tekanan udara tertentu sehingga bottle preform dapat mengembang dan membentuk sebuah profil atau produk yang diinginkan [16].

Dalam mesin blow molding, terdapat sebuah alat yang disebut injection blowing tools. Alat ini memiliki komponen bernama injection tools yang memiliki peran penting sebagai alat penginjeksi atau peniup udara bertekanan tinggi dari kompresor ke bottle preform lunak sehingga membuat bottle preform tersebut mengembang dan membentuk profil atau model yang diinginkan. Pada injection tools, material yang digunakan harus memiliki bobot yang ringan dan memiliki ketahanan terhadap pengaruh intensitas suhu tinggi dari bottle preform $\left( \pm 100^{\circ} \mathrm{C}\right)$ [3]. Injection blowing tools yang dipasangkan pada mesin blow molding harus memiliki kekuatan yang tinggi sehingga mampu menopang beban dari injection tools serta mold cavity. 


\section{Metode}

Tahapan proses perancangan ini berdasarkan diagram alur perancangan berikut.
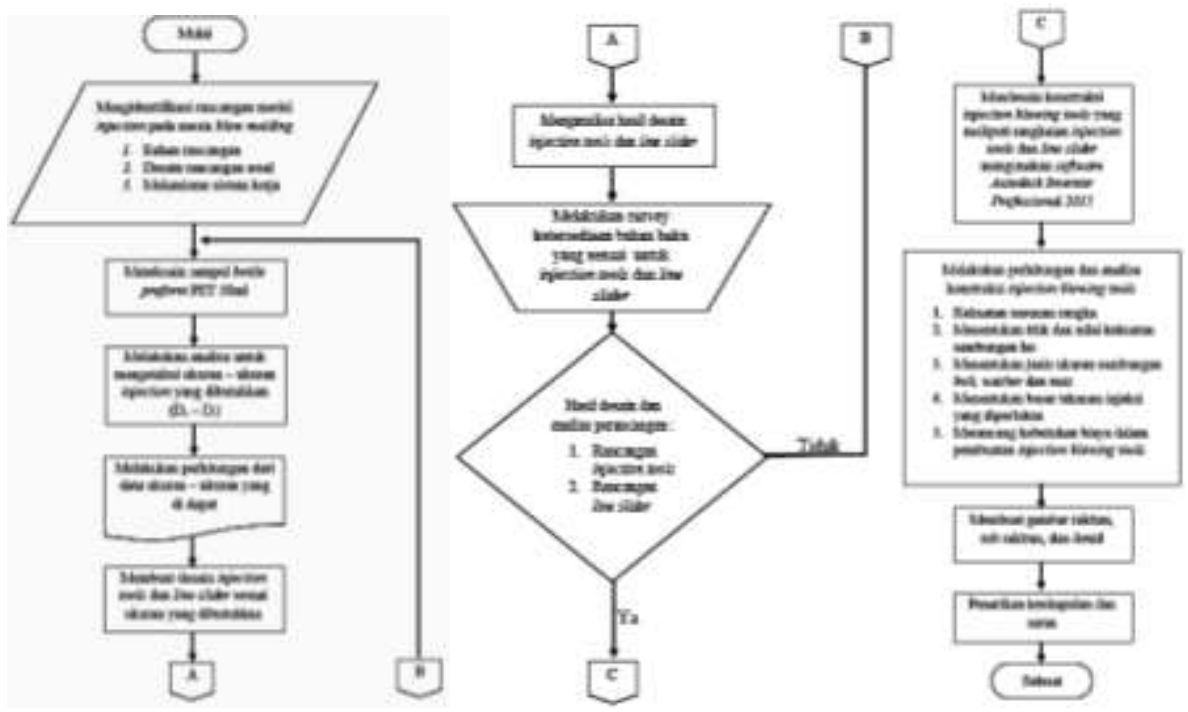

Gambar 2.1 Diagram Alur Perancangan

Injection blowing tools yang dirancang sesuai dengan ukuran untuk botol preform dengan diameter dalam $26 \mathrm{~mm}$ dan preform terbuat dari plastik jenis PET [3]. Selanjutnya, dilakukan identifikasi berdasarkan bahan baku (material) yang digunakan dan mekanisme sistem kerjanya untuk mengetahui rancangan awal dari injection blowing tools. Dalam proses tersebut, ditetapkan empat model perancangan awal. Setiap tahapan memiliki kelebihan dan kekurangan (gambar 2.2). Setelah pemilihan desain rancangan awal ditentukan (gambar 2.3), selanjutnya melakukan analisis pada rancangan tersebut, dimulai dari analisis rancang bangun mesin, kekuatan sambungan, kebutuhan sambungan, tekanan minimal yang harus diberikan, rasio pengembangan, dan proses perawatan yang harus dilakukan [21].
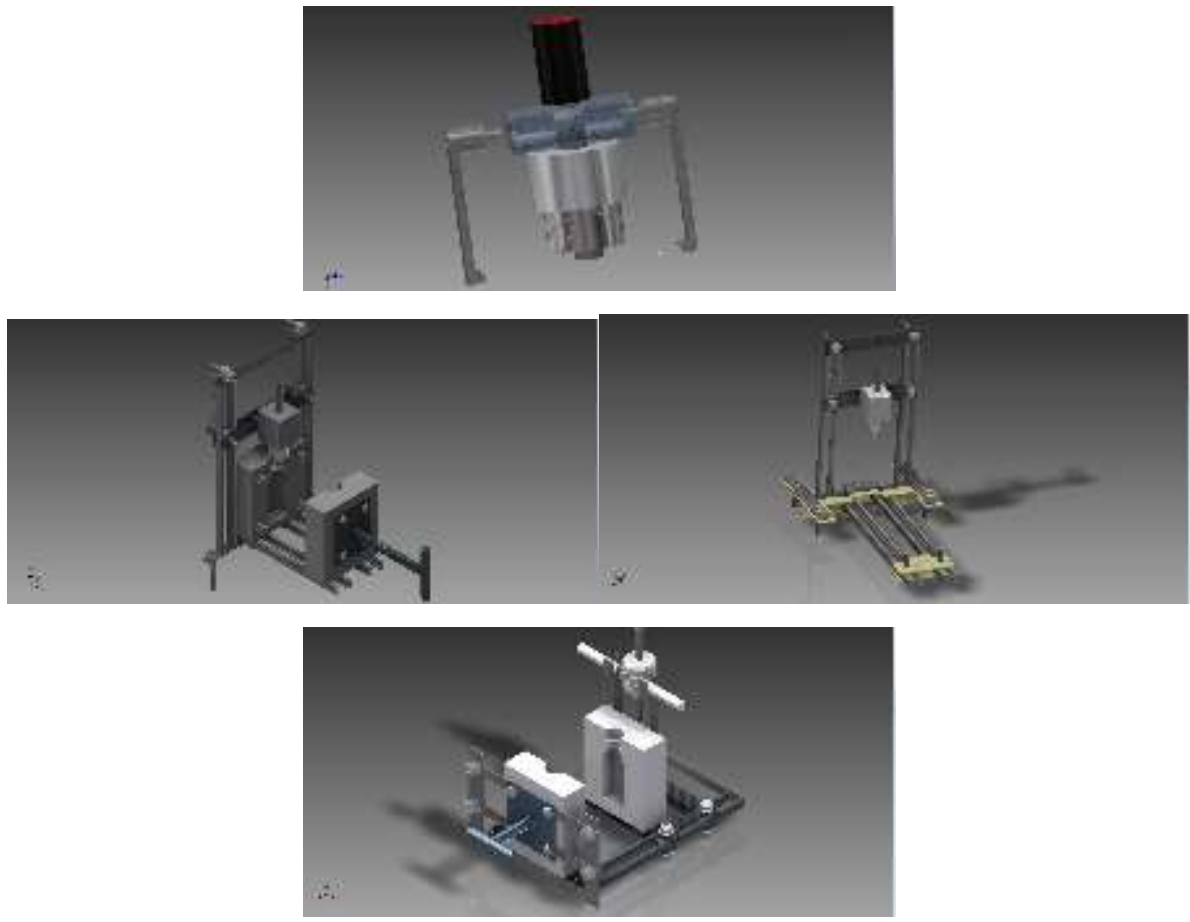

Gambar 2.2. Pilihan Kandidat Rancangan Awal 

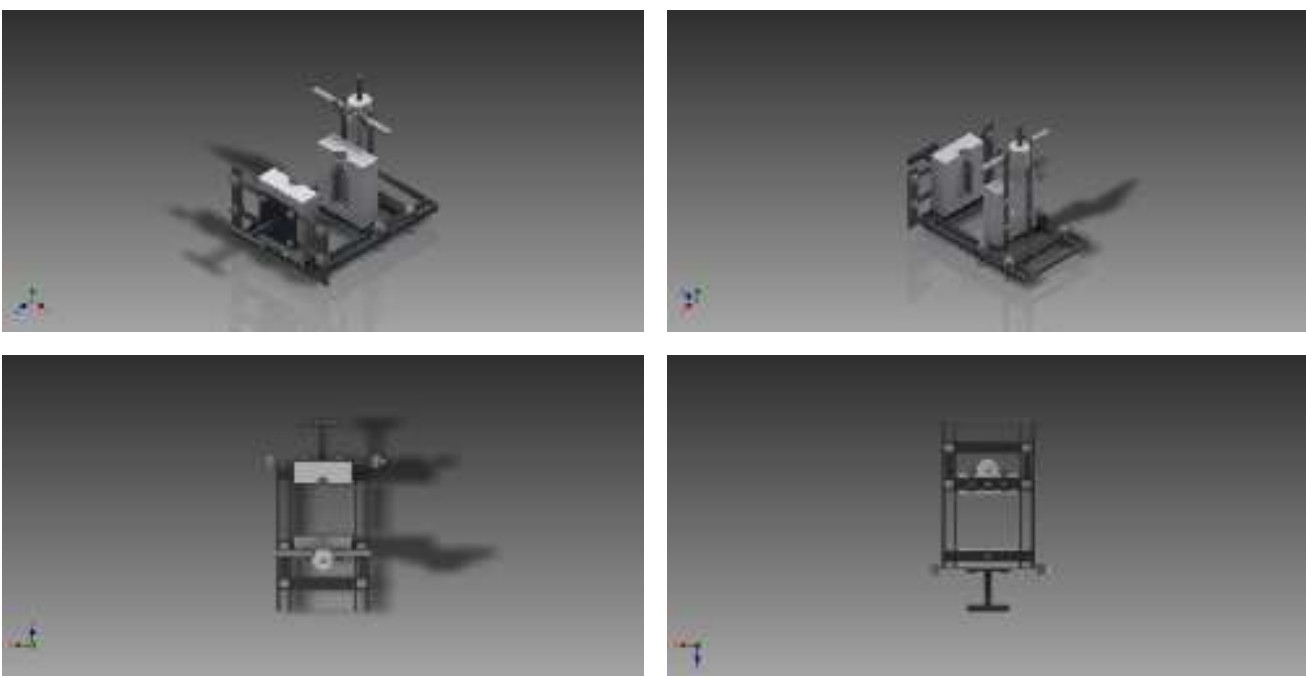

Gambar 2.3. Rancangan Awal Injection Blowing Tools

\subsection{Analisis dan Perhitungan Rancang Bangun Mesin}

Analisis ini bertujuan mengetahui berapa besar gaya yang terjadi dan beban pada komponen penyusun injection blowing tools. Beberapa komponen yang difokuskan dalam analisis ini yaitu pada bagian mold support plate, injection buffer pole, dan line slider. Tahapan dan persamaan atau rumus yang digunakan pada proses analisis perhitungan rancang bangun mesin adalah sebagai berikut [17]:

a. Menentukan arah gaya yang terjadi pada komponen.

b. Melakukan perhitungan gaya yang terjadi dengan acuan massa jenis material (1).

$$
\rho=\mathrm{m} / \mathrm{V}
$$

dengan $\rho=$ Massa Jenis $\left(\mathrm{kg} / \mathrm{m}^{3}\right)$ dan $V=$ Volume $\left(\mathrm{mm}^{3}\right)$

$F=\mathrm{m} \times \mathrm{g}$

dengan $\mathrm{m}$ adalah berat $(\mathrm{kg})$

$\mathrm{g}:$ Gravitasi $(9,81 \mathrm{~N} / \mathrm{kg})$

F : Gaya (N)

c. Melakukan analisis gaya gesek pada bagian yang terjadi gesekan.

$\mu s=\tan \theta$

$F s=\mu s x F a$

dengan $\theta=$ sudut Gesekan dan $\mu$ s = Koefisien Gesek

Fa : Gaya yang terjadi Fs: Gaya Gesek

d. Melakukan perhitungan redultan gaya yang terjadi .

$F r=\sqrt{A x^{2}+A y^{2}}$

dengan $A x$ : Gaya Horisontal (F.cos $\theta)$ dan $A y$ : Gaya Vertikal (F.sin $\theta$ )

e. Melakukan analisis tegangan yang terjadi

$\sigma n=F / A$

dengan $F$ : Gaya yang Terjadi (N) A : Luas Area $\left(\mathrm{mm}^{2}\right)$

f. Melakukan perbandingan tegangan yang terjadi dengan besar yield strength material. $y>\sigma n$

dengan $\mathrm{y}$ : yield strength $(\mathrm{Ksi}) \quad$ on : Tegangan (MPa) 


\subsection{Kekuatan Sambungan Las}

Analisis ini bertujuan mengetahui apakah kekuatan sambungan las [1] [9] yang digunakan (fillet-RD260-E6013) mampu menopang beban yang terjadi pada setiap komponen penyusun injection blowing tools with line slider. Beberapa komponen yang difokuskan dalam analisis ini yaitu pada bagian sambungan injection - handle, injection buffer pole, line slider - moveable mold plate,dan line slider - cover line. Tahapan dan persamaan atau rumus yang digunakan pada proses analisis perhitungan kekuatan sambungan las adalah sebagai berikut [23]:

a. Menentukan arah pembebanan pada komponen sambungan.

b. Mencari besar tegangan yang terjadi pada sambungan

$$
\begin{aligned}
& \sigma \text {-tarik }=F \sigma /(s \times L) \\
& \text { T-geser }=F T /(s \times L)
\end{aligned}
$$

bila diketahui:

$\sigma:$ Tegangan Tarik $\left(\mathrm{N} / \mathrm{m}^{2}\right)$

$\mathrm{s}$ : Tinggi Lasan ( $\mathrm{mm})$

$\mathrm{L}$ : Panjang Lasan (mm)

$\mathrm{r}$ : Tegangan Geser $\left(\mathrm{N} / \mathrm{m}^{2}\right)$

c. Menentukan tegangan terbesar yang terjadi pada sambungan

$$
\begin{aligned}
& \sigma(\max )=\sigma / 2 \pm 1 / 2 \sqrt{ }\left(\sigma^{\wedge} 2+4 \mathrm{~T}^{2}\right)(\mathrm{MPa}) \\
& \mathrm{T}(\max )=1 / 2 \sqrt{ }\left(\sigma^{\wedge} 2+4 \mathrm{~T}^{2}\right) \quad \text { (MPa) }
\end{aligned}
$$

d. Melakukan analisis perbandingan dari hasil perhitungan tegangan maksimal dengan nilai tegangan ijin dari elektroda yang digunakan pada proses pengelasan (untuk E6013, nilai tegangan ijinnya adalah 413,48 Mpa [9]

\subsection{Analisis Sambungan Bolt, Washer dan Nuts}

Analisis ini bertujuan menentukan jenis baut yang cocok digunakan untuk menyambung setiap komponen penyusun injection blowing tools with line slider. Beberapa komponen yang difokuskan dalam analisis ini yaitu pada bagian sambungan injection - handle, injection buffer pole, cantilever mold, handle - cantilever, and cantilever - bearing. Tahapan dan persamaan atau rumus yang digunakan pada proses analisis perhitungan sambungan bolt, washer, dan nuts adalah sebagai berikut [17]:

a. Menentukan arah pembebanan yang terjadi pada komponen.

b. Mencari besar nilai tegangan ijin pada sambungan.

$$
\text { oijin }=\frac{\text { omaks }}{v}
$$

bila diketahui:

$\sigma$ maks : Tegangan ljin Maks $\left(\mathrm{N} / \mathrm{mm}^{2}\right)$

$v$ : Safety Factor

c. Menentukan ukuran baut yang dibutuhkan untuk sambungan.

$d k=\sqrt{\frac{4 x F}{\pi x z x \sigma i \tilde{i} n}}$

bila diketahui:

$d k$ : Diameter Baut $(\mathrm{mm})$

$F$ : Gaya yang Terjadi $(\mathrm{N})$

$z$ : Jumlah Titik Sambungan 


\subsection{Analisis Tekanan Injeksi}

Analisis ini bertujuan menentukan besar tekanan minimal yang harus diberikan pada proses injeksi serta mengetahui nilai BUR (Blow Up Ratio) atau rasio perbandingan bentuk botol sebelum dan setelah proses injeksi dilakukan. Tahapan dan persamaan atau rumus yang digunakan pada proses analisis perhitungan tekanan injeksi adalah sebagai berikut [13] [20]:

a. Menentukan volume botol sebelum dan target botol (ukuran produk).

b. Mencari nilai tekanan minimal injeksi.

$$
P . V=C
$$

$$
\begin{array}{r}
P 1 . V 1=P 2 . V 2 \\
P 2=\frac{V 2}{P 1 . V 1}
\end{array}
$$

bila diketahui:

$\mathrm{P}_{1}$ : Tekanan Awal (Bar) $\mathrm{V}_{1}$ : Volume Preform $(\mathrm{ml})$

$\mathrm{P}_{2}$ : Tekanan Akhir (Bar) $\mathrm{V}_{2}$ : Volume Produk (ml)

c. Menentukan nilai BUR.

$$
\begin{aligned}
S R l=\frac{L b}{L p} S R h=\frac{D b}{D p} \\
B U R=S R l \times S R h
\end{aligned}
$$

bila diketahui:

$\mathrm{SR}_{\mid}$: Rasio Perbandingan Panjang

$\mathrm{SR}_{\mathrm{h}}$ : Rasio Perbandingan Lebar / D

$L_{B} \quad$ : Panjang Botol

$L_{P} \quad$ : Panjang Preform

$D_{B} \quad$ : Lebar / Diameter Botol

$D_{P} \quad$ : Lebar / Diameter Preform

\subsection{Gambar Teknik}

Metode ini dilakukan untuk menginterpretasikan hasil dari analisis dan perhitungan rancangan injection blowing tools yang telah dilakukan ke dalam bentuk gambar 2D dan 3D yang terdiri dari gambar detail, sub-assembling, dan assembling. Metode ini adalah metode terakhir yang dilakukan dalam proses perancangan sehingga hasil dari rancangan yang telah dibuat dapat menjadi bahan acuan dalam proses perakitan injection blowing tools.

\section{Hasil dan Pembahasan}

Hasil dari perancangan injection blowing tools yaitu dari pemilihan desain perancangan awal kemudian dilakukan beberapa perhitungan dan analisis dan dilakukan rancangan kebutuhan biaya dari pembuatan injection blowing tools. Berikut hasil dari perancangan injection blowing tools.

\subsection{Rancangan Injection Blowing Tools untuk Mesin Blow Molding}

Pada pemilihan kandidat rancangan untuk injection blowing tools terdapat empat buah rancangan (gambar 2.2) yang masing - masing memiliki perbedaan di antaranya dari segi material yang digunakan, cara penyambungan komponen penyusun, dan mekanisme kerjanya. 


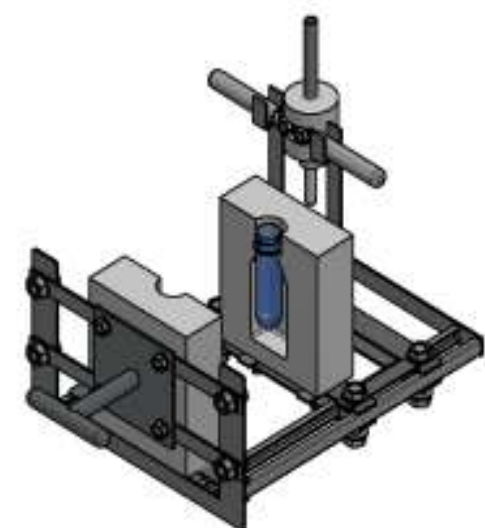

Gambar 3.1 Rancangan Awal Injection Blowing Tool

Dipilih rancangan dengan menggunakan material utama baja low carbon A36 $(0,25 \%$ $0,29 \%$ C) [6] [8] untuk bagian line slider dan aluminium 4032 [14] sebagai material pokok untuk bagian injection tools. Pemilihan material tersebut didasarkan dari kekuatan material tersebut, kemudahan proses, ketersediaan di pasaran Indonesia dan harga yang terjangkau.

\subsection{Hasil Analisis Perhitungan Rancang Bangun Mesin}

\subsubsection{Bagian Mold Support Plate}

Pada bagian mold support plate terjadi pembebanan yang diakibatkan oleh mold cavity seberat $3 \mathrm{~kg}$ untuk satu bagian, pembebanan dari gaya gesek yang terjadi, dan pengaruh gaya dari operator ketika mengoperasikan mesin. Maka dari itu, material yang digunakan adalah baja low carbon A36 [6]. Berikut hasil analisis bagian mold support plate.
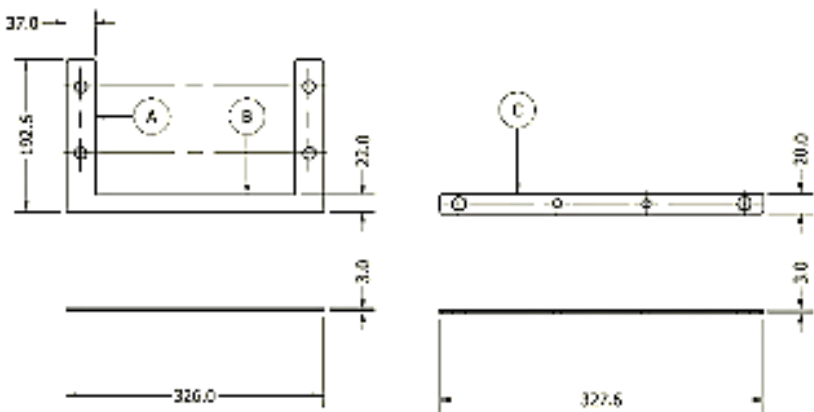

Gambar 3.2 Analisis Bagian Mold Support Plate

\subsubsection{Bagian Injection Buffer Pole}

Pada bagian injection buffer pole, terjadi pembebanan yang diakibatkan oleh beban dari injection tools seberat $1 \mathrm{~kg}$. Material yang digunakan adalah baja low carbon A36. Berikut hasil analisis bagian injection buffer pole.
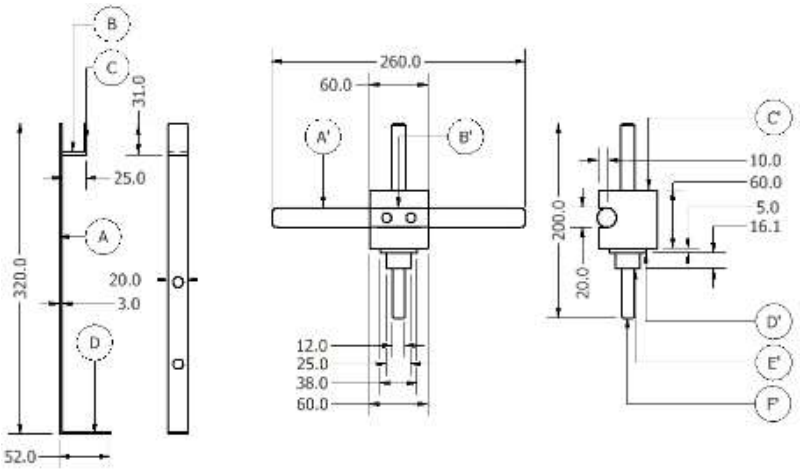

Gambar 3.3 Analisis Bagian Mold Support Plate 


\subsubsection{Bagian Line Slider}

Pada bagian line slider, terjadi pembebanan yang diakibatkan oleh beban dari mold cavity seberat $3 \mathrm{~kg}$ untuk satu bagian, pembebanan dari komponen penyangga mold cavity yang menyebabkan beban total sebesar $6,34 \mathrm{~kg}$. Material yang digunakan adalah baja low carbon A36.Berikut hasil analisis bagian line slider

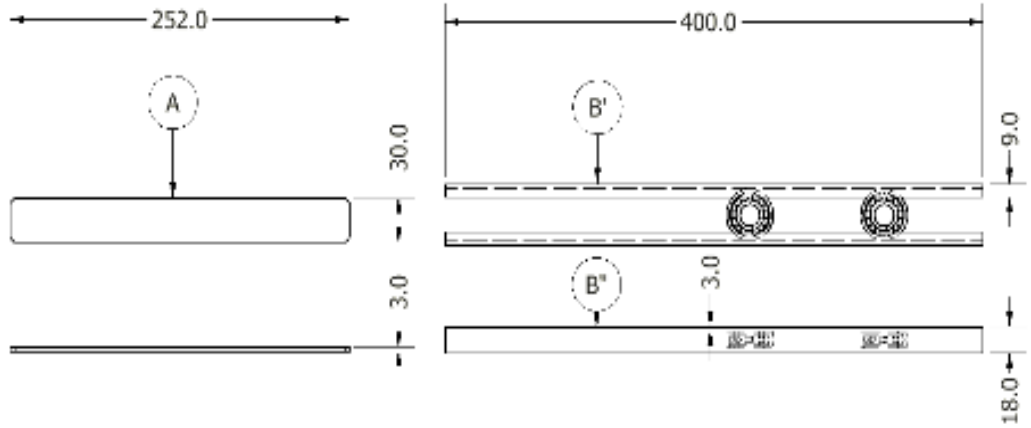

Gambar 3.4 Analisis Bagian Line Slider

Berikut adalah hasil analisis dan perhitungan rancang bangun dari komponen komponen peyusun injection blowing tools yang terdiri dari bagian mold support plate, injection buffer pole, dan line slider. Setiap komponen tersebut menerima pembebanan dan pengaruh gaya yang berbeda-beda.

Tabel 3.1 Hasil Perhitungan Rancang Bangun Mesin

\begin{tabular}{|c|c|c|c|c|c|c|c|c|c|c|c|c|}
\hline \multicolumn{13}{|c|}{ Hasil Analisa dan Perhitungan } \\
\hline \multicolumn{13}{|c|}{ Rancang Bangun Mesin } \\
\hline \multirow{2}{*}{ No } & \multirow{2}{*}{ Bagian } & \multicolumn{4}{|c|}{ Dimensi (mm) } & \multirow{2}{*}{$\begin{array}{c}\text { Jumlah } \\
\text { Komponen }\end{array}$} & \multicolumn{4}{|c|}{ Hasil Perhitungan } & \multicolumn{2}{|c|}{$\begin{array}{c}\text { Kesimpulan }(\gamma \\
>\sigma n)\end{array}$} \\
\hline & & $\mathrm{P}$ & $\mathrm{L}$ & $\mathrm{T}$ & $\begin{array}{c}- \\
\text { Bagian }\end{array}$ & & $\begin{array}{c}\text { Volume } \\
\left(\mathrm{mm}^{3}\right)\end{array}$ & $\begin{array}{l}\text { Berat } \\
(\mathrm{kg})\end{array}$ & $\begin{array}{c}\text { Gaya } \\
(\mathrm{N})\end{array}$ & $\sigma \mathrm{n}(\mathrm{MPa})$ & Aman & Tidak \\
\hline \multirow{3}{*}{3.1} & A & 192,6 & 37 & 3 & 22 & 2 & 18936,6 & 0,30 & \multirow{3}{*}{62,41} & \multirow{3}{*}{$4,334 \times 10^{-3}$} & \multirow{3}{*}{$\sqrt{ }$} & \multirow{3}{*}{ - } \\
\hline & $\mathrm{B}$ & 22 & 326 & 3 & 74 & 1 & 16632,0 & 0,13 & & & & \\
\hline & $\mathrm{C}$ & 20 & 327,6 & 3 & 0 & 2 & 19656,0 & 0,31 & & & & \\
\hline & Bagian & $\mathrm{P}$ & $\mathrm{L}$ & $\mathrm{T}$ & $\mathrm{r}$ & & & & & & & \\
\hline \multirow{10}{*}{3.2} & $\mathrm{~A}^{\prime}$ & 100 & - & - & 10 & 2 & 31415,93 & 0,47 & \multirow{10}{*}{9,99} & \multirow{10}{*}{$11,352 \times 10^{-3}$} & \multirow{10}{*}{$\sqrt{ }$} & \multirow{10}{*}{ - } \\
\hline & $\mathrm{B}^{\prime}$ & 20 & 60 & 3 & - & 1 & 3600 & 0,03 & & & & \\
\hline & $\mathrm{C}^{\prime}$ & - & - & 60 & 30 & \multirow{3}{*}{1} & 169646 & \multirow{3}{*}{0,44} & & & & \\
\hline & $\mathrm{C}^{\prime \prime}$ & 20 & 60 & 10 & - & & 12000 & & & & & \\
\hline & $\mathrm{C}$ & & $\mathrm{C}^{\prime}$ & $\mathrm{C}^{\prime \prime}$ & & & 157646 & & & & & \\
\hline & $\mathrm{D}^{\prime}$ & - & - & 5 & 19 & 1 & 5670,6 & 0,016 & & & & \\
\hline & $E^{\prime}$ & - & - & 16,1 & 12,5 & 1 & 7903,1 & 0,022 & & & & \\
\hline & $\mathrm{F}^{\prime}$ & - & - & 200 & 6 & \multirow{3}{*}{1} & 22619,47 & \multirow{3}{*}{0,05} & & & & \\
\hline & $F^{\prime \prime}$ & - & - & 200 & 5 & & 15707,96 & & & & & \\
\hline & $\mathrm{F}$ & & $\mathrm{F}^{\prime}$ & & & & 6911,50 & & & & & \\
\hline \multirow{4}{*}{3.3} & $\mathrm{~A}$ & 252 & 30 & 3 & - & 2 & 22680 & 0,35 & \multirow{4}{*}{62,2} & \multirow{4}{*}{$0,056 \times 10^{-3}$} & \multirow{4}{*}{$\sqrt{ }$} & \multirow{4}{*}{ - } \\
\hline & $\mathrm{B}^{\prime}$ & 400 & 18 & 3 & - & \multirow{3}{*}{2} & 21600 & \multirow{3}{*}{0,50} & & & & \\
\hline & $\mathrm{B}^{\prime \prime}$ & 400 & 9 & 3 & - & & 10800 & & & & & \\
\hline & $\mathrm{B}$ & \multicolumn{4}{|c|}{$\mathrm{B}^{\prime}+\mathrm{B}^{\prime \prime}$} & & 32400 & & & & & \\
\hline
\end{tabular}

\subsection{Hasil Analisis Perhitungan Kekuatan Sambungan Las}

Berikut adalah hasil analisis dan perhitungan kekuatan sambungan las yang dalam perancangan injection blowing tools menggunakan las SMAW dengan model fillet concave dengan elektroda RD-260 jenis E6013 (60 Ksi) [23] dengan rata - rata tinggi leher las $3 \mathrm{~mm}$ dan panjang berkisar $6 \mathrm{~mm}$ sampai $20 \mathrm{~mm}$. Setiap sambungan memiliki pembebanan yang berbeda-beda. Berikut tabel hasil perhitungan dan titik rancangan sambungan las. 


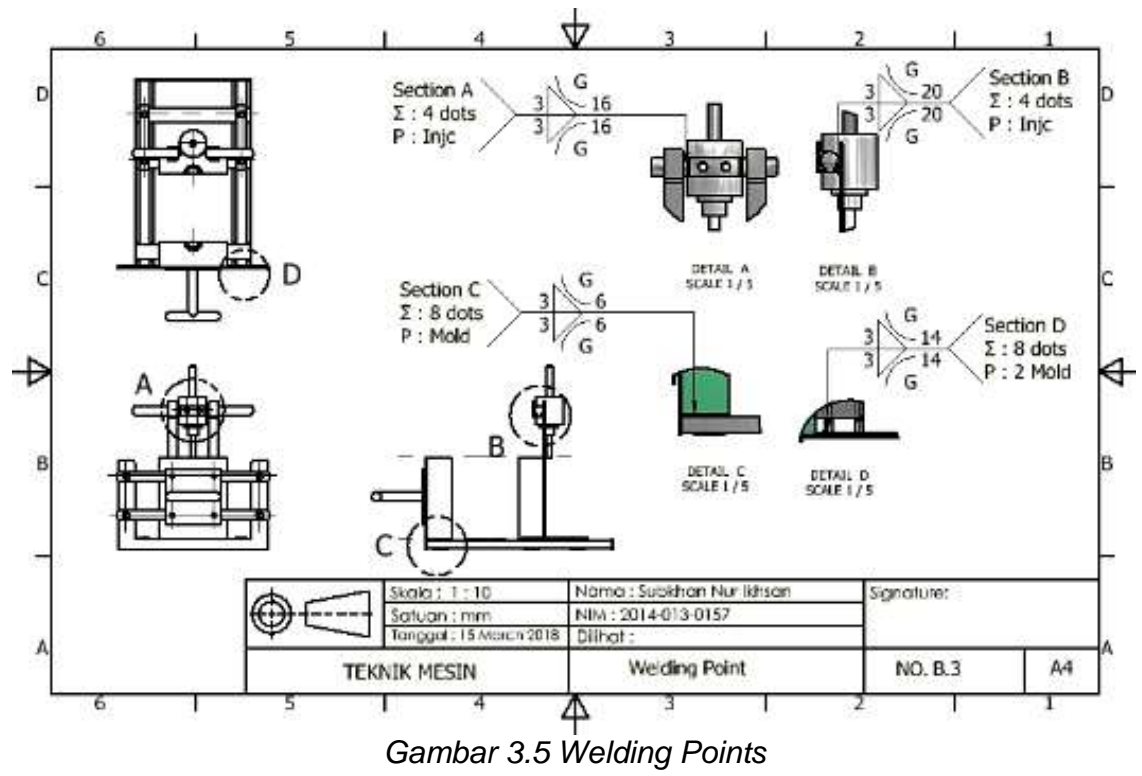

Tabel 3.2 Keterangan Welding Points

\begin{tabular}{ccccc}
\hline Bagian & $\begin{array}{c}\text { Tinggi } \\
\text { Lassan }\end{array}$ & Panjang Lassan & $\begin{array}{c}\text { Jumlah } \\
\text { Titik }\end{array}$ & Pengaruh Pembebanan \\
\hline A & $3 \mathrm{~mm}$ & $16 \mathrm{~mm}$ & 4 & Injection \\
B & $3 \mathrm{~mm}$ & $20 \mathrm{~mm}$ & 4 & Injection + material base \\
C & $3 \mathrm{~mm}$ & $6 \mathrm{~mm}$ & 8 & Mold (1 side $)$ \\
D & $3 \mathrm{~mm}$ & $14 \mathrm{~mm}$ & 8 & Mold (2 side $)$
\end{tabular}

Tabel 3.3 Hasil Perhitungan Kekuatan Sambungan Las

\begin{tabular}{|c|c|c|c|c|c|c|c|c|c|}
\hline \multicolumn{10}{|c|}{ Hasil Analisa dan Perhitungan } \\
\hline \multicolumn{10}{|c|}{ Kekuatan Sambungan Las } \\
\hline \multirow{2}{*}{ Bagian } & \multicolumn{2}{|c|}{ Dimensi (mm) } & \multirow{2}{*}{ Jumlah Titik } & \multicolumn{4}{|c|}{ Hasil Perhitungan } & \multicolumn{2}{|c|}{$\begin{array}{c}\text { Kesimpulan } \\
\text { (E.maks < E.ijin) }\end{array}$} \\
\hline & $\mathrm{s}$ & $\mathrm{L}$ & & $\begin{array}{l}\sigma . \max \\
(\mathrm{MPa})\end{array}$ & $\begin{array}{l}\tau . \max \\
(\mathrm{MPa})\end{array}$ & E. Maks & E.Ijin & Aman & Tidak \\
\hline A & 3 & 16 & 4 & 0,06 & 0,10 & 0,10 & 413,48 & $\sqrt{ }$ & - \\
\hline B & 3 & 20 & 4 & 0,11 & 0,09 & 0,11 & 413,48 & $\sqrt{ }$ & - \\
\hline $\mathrm{C}$ & 3 & 6 & 8 & 0,42 & 0,41 & 0,42 & 413,48 & $\sqrt{ }$ & - \\
\hline $\mathrm{D}$ & 3 & 14 & 8 & 2,60 & 2,10 & 2,60 & 413,48 & $\sqrt{ }$ & - \\
\hline
\end{tabular}

\subsection{Hasil Analisis Sambungan Bolt dan Nut}

Berikut adalah hasil analisis dan perhitungan sambungan bolt dan nuts bahwa dalam perancangan injection blowing tools digunakan baut yang terbuat dari material SS304-Mili dengan batas tegangan maksimal sebesar $515 \mathrm{MPa}$ [22]. Setiap sambungan memiliki pembebanan yang berbeda-beda. Berikut tabel hasil perhitungan sambungan bolt, washer, dan nuts. 


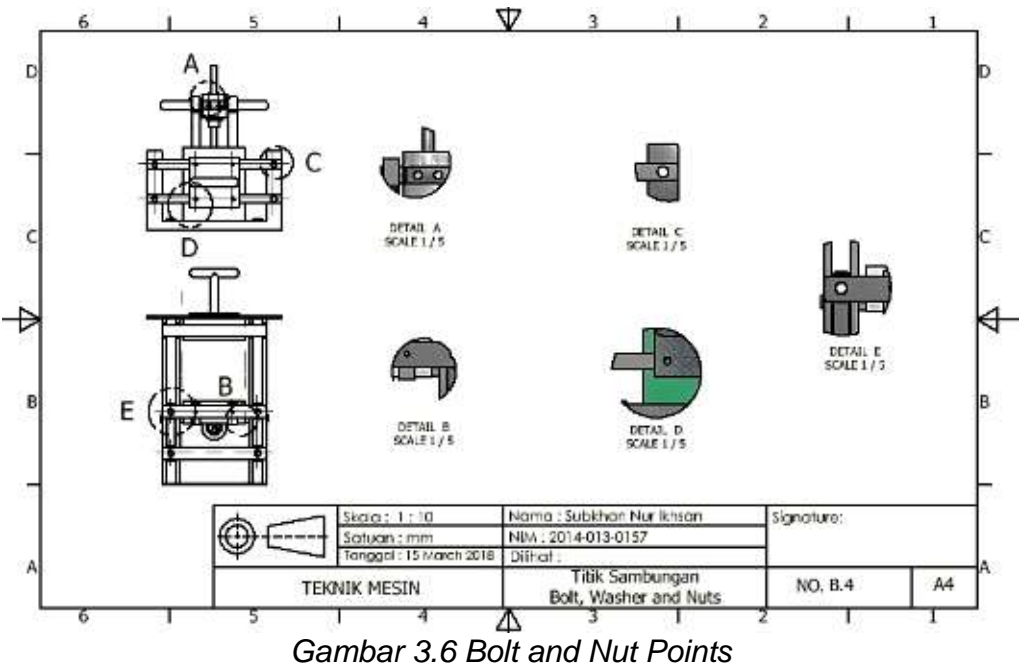

Tabel 3.4 Hasil Perhitungan Kekuatan Sambungan Bolt dan Nut

\begin{tabular}{|c|c|c|c|c|c|c|c|c|c|}
\hline \multicolumn{10}{|c|}{ Hasil Analisa dan Perhitungan } \\
\hline \multicolumn{10}{|c|}{ Sambungan Bolt, Washer, and Nuts } \\
\hline \multirow[b]{2}{*}{ Bagian } & \multirow[b]{2}{*}{$\begin{array}{c}\text { Jenis } \\
\text { Sambungan }\end{array}$} & \multirow[b]{2}{*}{$\begin{array}{c}\text { Jumlah } \\
\text { Titik }\end{array}$} & \multicolumn{5}{|c|}{ Hasil Perhitungan } & \multicolumn{2}{|c|}{ Kesimpulan } \\
\hline & & & $\begin{array}{c}\text { Besar } \\
\text { Pembebanan } \\
\text { (N) }\end{array}$ & $\begin{array}{l}\text { Safety } \\
\text { Factor }\end{array}$ & $\begin{array}{l}\sigma . \max \\
(\mathrm{MPa})\end{array}$ & $\begin{array}{c}\sigma . \text { ijin } \\
(\mathrm{MPa})\end{array}$ & $\begin{array}{c}\text { Diameter } \\
(\mathrm{mm})\end{array}$ & $\begin{array}{l}\text { Ukuran } \\
\text { Pasti }\end{array}$ & $\begin{array}{c}\text { Ukuran } \\
\text { Alternatif }\end{array}$ \\
\hline $\mathrm{A}$ & Tap & 2 & 10,13 & 4,5 & 515 & 114,44 & 0,24 & M 0,4 & M 10 \\
\hline $\mathrm{B}$ & Jepit & 2 & 3,00 & 2,0 & 515 & 257,50 & 0,09 & M 0,4 & M 6 \\
\hline $\mathrm{C}$ & Jepit & 4 & 29,43 & 4,5 & 515 & 114,44 & 0,29 & M 0,6 & M 16 \\
\hline $\mathrm{D}$ & Tap & 4 & 29,43 & 4,5 & 515 & 114,44 & 0,29 & M 0,6 & M 10 \\
\hline $\mathrm{E}$ & Jepit & 4 & 3,00 & 4,5 & 515 & 114,44 & 0,09 & M 0,4 & M 16 \\
\hline
\end{tabular}

\subsection{Hasil Analisis Tekanan Injeksi}

Berikut adalah hasil analisis dan perhitungan tekanan udara minimal yang dibutuhkan untuk proses injeksi untuk membuat produk botol dengan volume $300 \mathrm{ml}$ dari preform PET dengan volume $50 \mathrm{ml}$ pada mesin blow molding.

Tabel 3.5 Dimensi Preform dan Produk Botol

\begin{tabular}{|c|c|c|c|c|c|}
\hline \multicolumn{6}{|c|}{ Bottle Preform } \\
\hline Bagian & Bentuk & \multicolumn{2}{|c|}{ Ukuran } & \multicolumn{2}{|c|}{ Volume $\left(\mathrm{mm}^{3}\right)$} \\
\hline \multirow{2}{*}{ A } & \multirow{2}{*}{ Tabung } & $\mathrm{D}$ & 28 & \multirow{2}{*}{45659,9} & \multirow{3}{*}{50,26} \\
\hline & & $\mathrm{T}$ & 86 & & \\
\hline B & Setengah Bola & $\mathrm{r}$ & 13 & 4601,39 & \\
\hline \multicolumn{6}{|c|}{ Produk Botol } \\
\hline Bagian & Bentuk & \multicolumn{2}{|c|}{ Ukuran } & \multicolumn{2}{|c|}{ Volume $\left(\mathrm{mm}^{3}\right)$} \\
\hline \multirow{2}{*}{ A } & \multirow{2}{*}{ Tabung } & $\mathrm{D}$ & 26 & \multirow{2}{*}{7693,16} & \multirow{7}{*}{323,9} \\
\hline & & $\mathrm{T}$ & 14,5 & & \\
\hline \multirow{2}{*}{ B } & \multirow{2}{*}{ Limas Segi Empat } & $\mathrm{s}$ & 55 & \multirow{2}{*}{31510,84} & \\
\hline & & $\mathrm{T}$ & 24,4 & & \\
\hline \multirow{3}{*}{$\mathrm{C}$} & \multirow{3}{*}{ Balok } & $\mathrm{P}$ & 55 & \multirow{3}{*}{284682,8} & \\
\hline & & $\mathrm{L}$ & 55 & & \\
\hline & & $\mathrm{T}$ & 94,1 & & \\
\hline
\end{tabular}


Proses mencari tekanan minimal yang diperlukan untuk injeksi $\left(P_{2}\right)$ adalah sebagai berikut.

$P 1 . V 1=P 2 . V 2 \rightarrow$ untuk menyamaratakan perbandingan maka,

$P 2=\frac{V 2}{P 1 \cdot \frac{1}{3}} \rightarrow P 2,93 \mathrm{ml}$
$P 2=\frac{3 \mathrm{psi}=1,7225 \mathrm{bar}}{1 \mathrm{Bar} \cdot 50,26 \mathrm{ml}}=\mathbf{6 , 6 2} \mathrm{Bar} \rightarrow \mathbf{7 ~ B a r}$

Dengan analisis Blow Up Ratio diketahui ratio peniupan atau injeksi pada bottle preform [20].

$$
\begin{aligned}
& S R l=\frac{L b}{L p}=\frac{134,99 \mathrm{~mm}}{99 \mathrm{~mm}}=1,36 \quad S R h=\frac{D b}{D p}=\frac{79 \mathrm{~mm}}{26 \mathrm{~mm}}=3,04 \\
& B U R=S R l \times S R h=1,36 \times 3,04=4,13 \rightarrow 4
\end{aligned}
$$

Dapat disimpulkan, tekanan yang harus diberikan pada proses injeksi dari botol preform ke botol produk, dibutuhkan tekanan minimal 7 Bar dengan besar ratio pengembangan dari bottle preform ke bentuk botol produk sebesar 4 (dengan suhu titik leleh PET $100^{\circ} \mathrm{C}$ normal pada proses blow molding).

\subsection{Hasil Akhir Perancangan}

Berikut adalah hasil rancangan injection blowing tools untuk botol bermaterial PET dengan diameter dalam $26 \mathrm{~mm}$ berskala prototype.

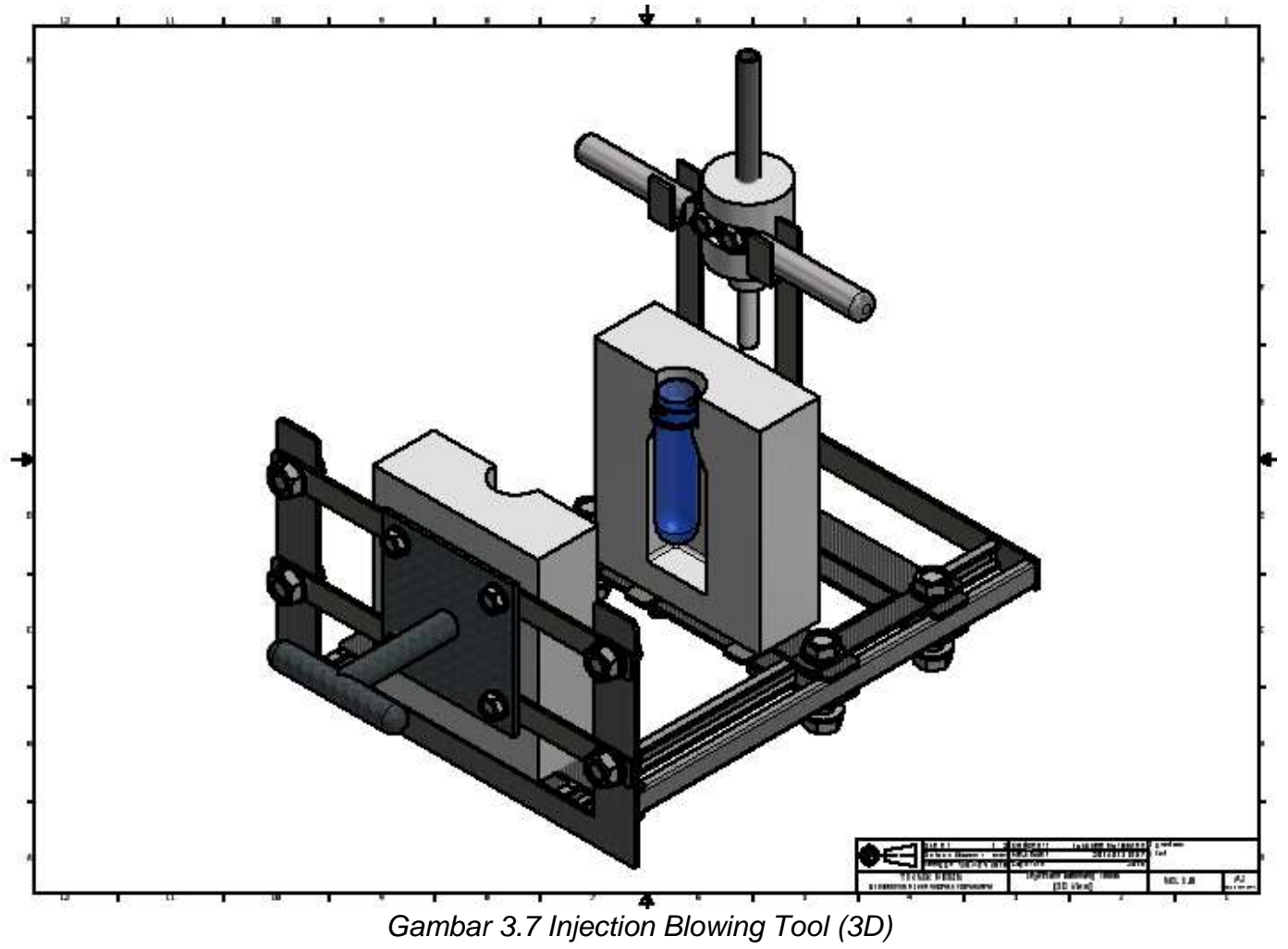



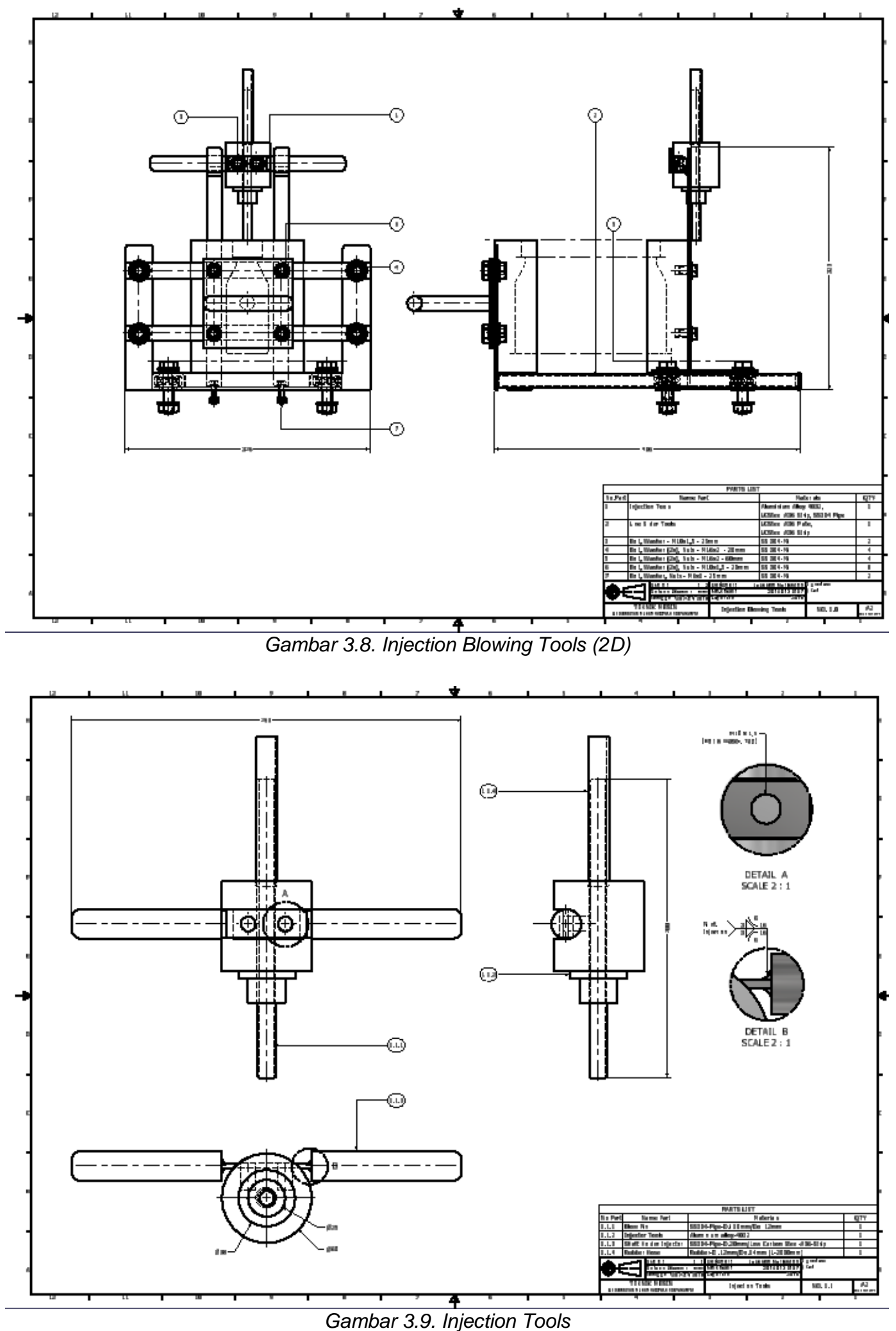


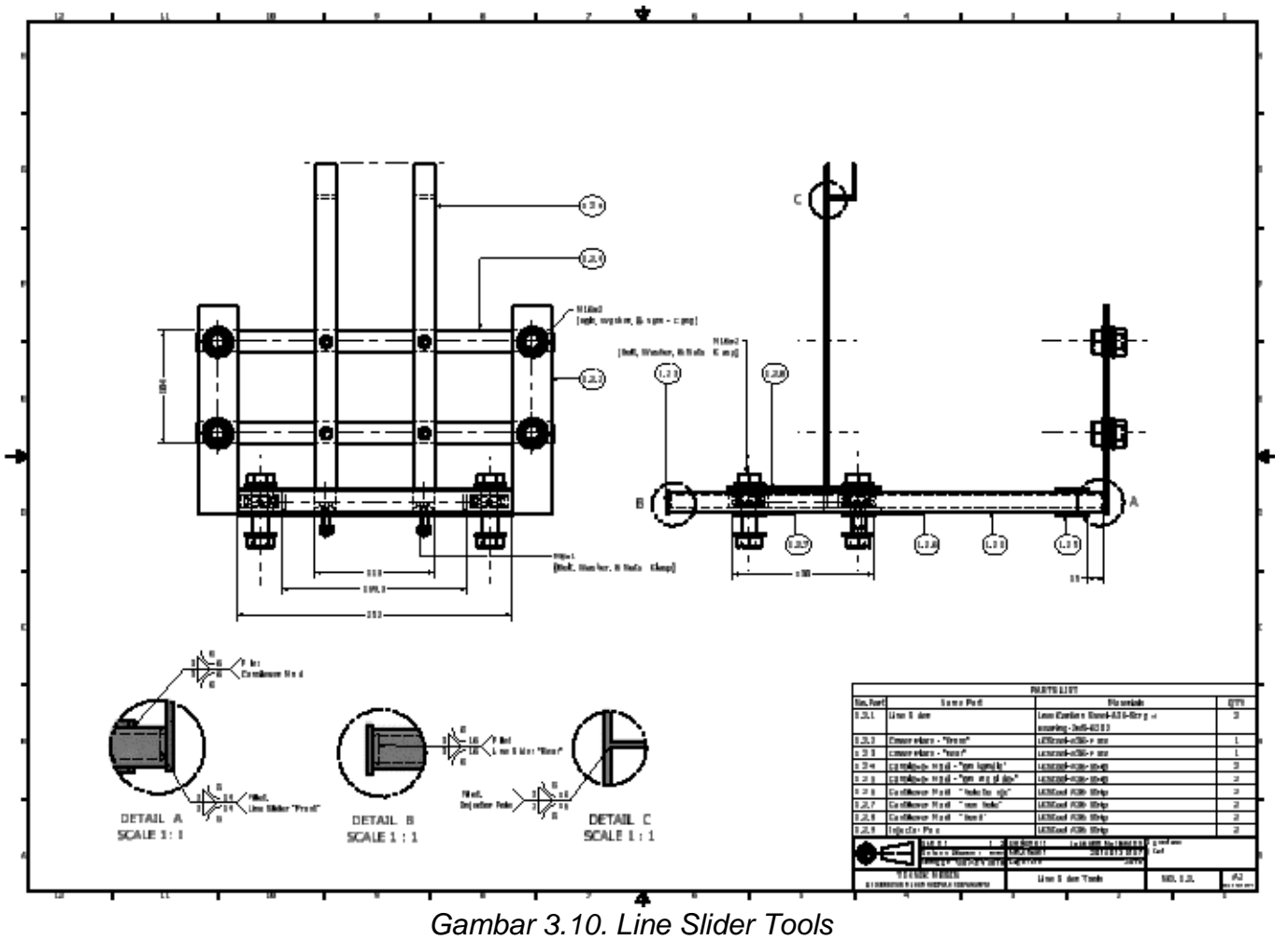

\section{KesimpUlan}

Bedasarkan hasil perancangan Injection Blowing Tools dengan Line Slider untuk mesin Blow Molding dengan kapasitas volume $300 \mathrm{ml}$, dapat diambil kesimpulan sebagai berikut:

1. Hasil perancangan Injector Blowing Tools with Line Slider mendapatkan dimensi alat P.400mm L.325mm T.245mm dengan menggunakan dua jenis cara penyambungan, yaitu sambungan las dan baut-mur.

2. Hasil perancangan Injector Blowing Tools with Line Slider menggunakan material baja low carbon jenis A36 (plat-strip), Aluminium alloy-4032, SS304.

3. Hasil perancangan Injector Blowing Tools with Line Slider mendapatkan besar tekanan minimal yang harus digunakan pada proses blow air injection sebesar 7 Bar dengan rasio pengembangan sebesar 4 kali.

\section{Daftar Pustaka}

[1] Affi, Jon., Pengaruh Lapisan Oksida Tambahan pada Elektroda E6013 Terhadap Sifat Mekanik dan Struktur Mikro Lasan Baja Karbon Rendah. Jurnal Teknik Mesin. Universitas Andalas. Sumatra Barat. 2007.

[2] Anggaretno, Gita., Analisis Pengaruh Jenis terhadap Laju Korosi pada Pengelesan Pipa API 5L Grade X65 dengan Media Korosi FeCl3. Jurnal Teknik ITS. Institut Teknologi Sepuluh Nopember. 2012.

[3] Krismasurya, P.A. Pendekatan Six Sigma untuk Mengurangi Defect pada Proses Pembuatan Botol Plastik di Mesin Blow Molding ASB 2000ml. Jurnal Rekayasa dan Manajemen Sistem Industri. 2015; Vol.3 No.1.

[4] Kumar, Sachin. Panda, A. dan Singh, R.K. A Review on Tertiary Recycling of HighDensity Polyethylene to Fuel, Resources, Conservation and Recycling. International Journal of Sustainable Resource Management and Enviromental Efficiency. Elsevier. India. 2011. 
[5] Majanastra, R.B.S. Analisis Sifat Mekanik dan Struktur Mikro Hasil Proses Hydroforming Pada Material Tembaga (Cu) C84800 dan Aluminium Al 6063. Jurnal Ilmiah Teknik Mesin. 2016: Vol.4, No.2.

[6] Masryukan., Penelitian Sifat Fisis dan Menkanisme Baja Karbon Rendah Akibat Pengaruh Proses Pengarbonan dari Arang Kayu Jati. Jurnal Penelitian: Media Mesin. 2006: Vol.7, No.1.

[7] Mujiarto, Iman., Sifat dan Karakteristik Material Plastik dan Bahan Aditif. Jurnal, Traksi. 2005: Vol.3 No.2, Desember 2005. AMNI Semarang. Semarang,

[8] Murtiono, Arief., Pengaruh Quenching dan Tempering Terhadap Kekerasan dan Kekuatan Tarik Serta Struktur Mikro Baja Karbon Sedang untuk Mata Pisau Pemanen Sawit. Jurnal e-Dinamis, 2012: Volume II, No.2.

[9] Saputra, Trisna Jaya. Elektroda untuk Pengelasan Baja Lunak. Jurnal Teknik 2004: vol.22 no.2.

[10] Surono, U.B. Berbagai Metode Konversi Sampah Plastik Menjadi Bahan Bakar Minyak. Jurnal Jurusan Teknik Mesin. 2013.

[11] Kazmer, David. Simulation of the Blow Molding and Thermoforming Processes. The International Industrial Engineering Conference. Chicago. IL. 1992: 269-275.

[12] Ashby, M.F. Engineering Materials. Volume 2. Butterworth: Heinemann. 1998.

[13] Belcher, Samuel. L., Practical Guide to Injection Blow Molding. South Carolina:Taylor \& Francis Group. 2007.

[14] Davis, J.R., Aluminium and Aluminium Alloy. Ohio: ASM International. 1994.

[15] Domininghaus, Hans., Plastics for Engineers: Material, Applications. Processes. New York: Hanser Gardener. 1993.

[16] Harper, Charles A. Plastic Processes. Maryland: Wiley. 2006: 305.

[17] Irawan, Agustinus Purna. Diktat Elemen Mesin. Jurusan Teknik Mesin Fakultas Teknik. Jakarta: Diktat Universitas Tarumanegara. 2009.

[18] Klein, Rolf. Laser Welding of Plastics, First Edition. Maryland: Wiley. 2011.

[19] Kutz, Mayer. Applied Plastics Engineering Handbook. UK: The Boulevard, Elsevier. 2011: 205.

[20] Norman, C. Lee. Understanding Blow Molding, Second Edition. North Carolina: Hanser. 2000.

[21] Rees, Herbert. Understanding Product Design for Injection Molding. Orangeville, Ontario: Hanser. 1994: 8.

[22] Setiawan, Agus. Perencanaan Struktur Baja dengan Metode LRFD (sesuai SNI 031729-2002). Semarang: Erlangga. 2008.

[23] Winarto. Teknologi Pengelasan. Indonesia: Indonesian Welding Society. 2011.

[24] Amri, Alfan. Pengaruh Pendinginan Dalam Proses Injection Molding Pembuatan Acetabular Cup Pada Sambungan Hip. Universitas Muhammadiyah Surakarta. 2009. 